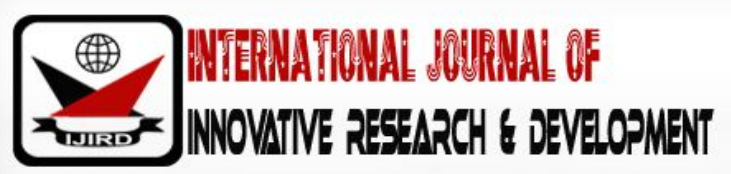

ISSN 2278 - 0211 (Online)

\section{Synergestic Effect of Vernonia Amygdalina and Glimepiride on Alloxan Induced Hyperglycaemia}

\author{
Christian Onahinon \\ Co-Researcher, Department of Human Physiology, Benue State University, Nigeria \\ Dr. Emmanuel Eru \\ Lecturer, Department of Physiology, Benue State University, Nigeria \\ Dr .Julie Ibu \\ Chief Inspector, National Youth Service Corps, Benue State Secretariat Makurdi, Nigeria \\ Dr. Nndunno Akwaras \\ Senior Registrar, Federal Medical Centre, Nigeria
}

\begin{abstract}
:
Glimepiride is a sulfonylurea whose mechanism of action is to stimulate insulin release from the beta cell of the pancreas. It is an oral hypoglycaemic agent that is widely used in the management of type 2 Diabetes mellitus in Nigeria. Also, Vernonia amygdalina (VA) is a common shrub consumed in Nigeria. This study was done to investigate the effect of VA and glimepiride in alloxan induced hyperglycaemia. Twenty five (25) adult Wister albino rats of both sexes weighing 200-250g were randomly allocated into five (5) groups with five (5) rats per group. Group 1 was given normal saline alone without inducing hyperglycaemia in the group to serve as normoglycaemic control while animals in group 2, 3, 4 and 5 were given $65 \mathrm{mg} / \mathrm{kg}$ bodyweight of alloxan monohydrate to induce hyperglycaemia according to the method of Osikwe et al., 2015, Onahinon et al.,2018. After inducing hyperglycaemia, group 2 were given normal saline, group 3,100mg/ $\mathrm{kg}$ body weight of VA, group 4, 2mg/ $\mathrm{kg}$ body weight of glimepiride and group 5, $100 \mathrm{mg} / \mathrm{kg}$ body weight of VA and $2 \mathrm{mg} / \mathrm{kg}$ body weight of glimepiride for a duration of 2 weeks. The result showed that the fasting blood glucose of group 1 was $81 \pm 2.8 \mathrm{mg} / \mathrm{dl}$. The fast blood glucose of group 2 was $283 \pm 8.3$ vs $340 \pm 20.3 \mathrm{mg} / \mathrm{dl}$, group 3 was $304 \pm 3.8198 \pm 3.3 \mathrm{mg} / \mathrm{dl}$, group 4 was $308 \pm 3.3$ vs $216 \pm 1.5 \mathrm{mg} / \mathrm{dl}$ and group 5 was $333 \pm 8.9 \mathrm{vs} 151 \pm 5.1 \mathrm{mg} / \mathrm{dl}$. There was significant difference in the basal fasting blood glucose and fasting blood glucose after induction $(\mathrm{p}<0.01)$. There was significant difference between group 2 and group 3 , group 2 and group 4, and group 2 and group 5 ( $\mathrm{p}<0.01$ ). There was no significant difference between group 3 and group 4 ( $p>0.05)$ however, the percentage change in fasting blood glucose in group 3 and 4 after hypoglycaemic agents were administered were $34.9 \%$ and $29.9 \%$ respectively. There was a significant difference between group 5 and group 3, and group 5 and group $4(\mathrm{p}<0.01)$. The percentage change in fasting blood glucose of group $2,3,4$, and 5 were $20.1 \%,-34.9 \%,-29.9 \%$ and $-54.7 \%$ respectively. It is concluded that there is synergism between VA and glimepiride.
\end{abstract}

Keyword: Vernonia amygdalina, glimepiride, alloxan induced hyglycaemia, fasting blood glucose

\section{Introduction}

Diabetes mellitus is a complex and chronic metabolic disorder characterized by a sustained hyperglycaemia with a fasting blood glucose $\geq 126 \mathrm{mg} / \mathrm{dl}$, with disturbances of carbohydrate, fat and protein metabolism,high oxidative stress induced by the generation of highly reactive free radicals which are also involved in pancreatic destruction (Sharma et al.,2010) whichresult from defects in insulin secretion, insulin action, or both (Kjems et al., 2001).Despite the wide use of currently available oral hypoglycaemic drug the progressive deterioration of diabetes control is such that treatment is still insufficient, with the majority of type 2 diabetes patients eventually requiring insulin therapy to achieve targeted glycaemic levels (Turner et al.,2000). Due to the etiopathogenesis of diabetes mellitus, harmful side effects of synthetic drugs, the inability ofexisting modern therapies to control all the pathological aspects of the diabetic disorder, enormous cost of moderndrugs as well as the poor availability of the advanced therapies for many rural populations in developing countries(Tanaka et al., 1992), alternative strategies to current pharmacotherapy of diabetes mellitus are urgently needed. Currently, available therapies for diabetes include, insulin secretagogues (sulfonylureas, meglitinides), insulin sensitizers (biguanides, thiazolidinedione), agents that enhance incretin secretion and action (incretin analogues, incretin mimetics, 
dipeptidyl peptidase IV (DPP-IV) inhibitors), agents that decrease gastrointestinal glucose absorption (alpha glucosidase inhibitors, alpha amylase inhibitors, sodium-glucose co-transporter (SGLT-1) selective inhibitors), agents that promote renal glucose excretion (sodium-glucose co-transporter (SGLT-2) inhibitors) and others (amylin analogue, bile acid sequesterants, bromocriptine) (Verspohl, 2012).

Presently, there is growing interest in herbal remedies due to the multimodal approach required in the management of diabetes mellitus couple with the cost, non availability, side effects associated with the oral hypoglycemic agents (Tiwari and Rao, 2002). Ethnobotanical and ethnopharmacological surveys report that more than 1200 plants are being used in many ethnic societies around the world in traditional medicine for their alleged hypoglycemic activity (Akah et al.,2002) and Vernonia amygdalina is one of them and could exhibit synergism with some current available oral hypoglycaemic drug.

\section{Materials and Method}

Fresh leaves of V. amygdalina were collected from the natural habitat in Makurdi, Benue State, Nigeria. The leaves were confirmed by a taxonomist from the Department of Botany in the Faculty of Science, Benue State University and was allocated a voucher number and deposited in the herbarium of the department.

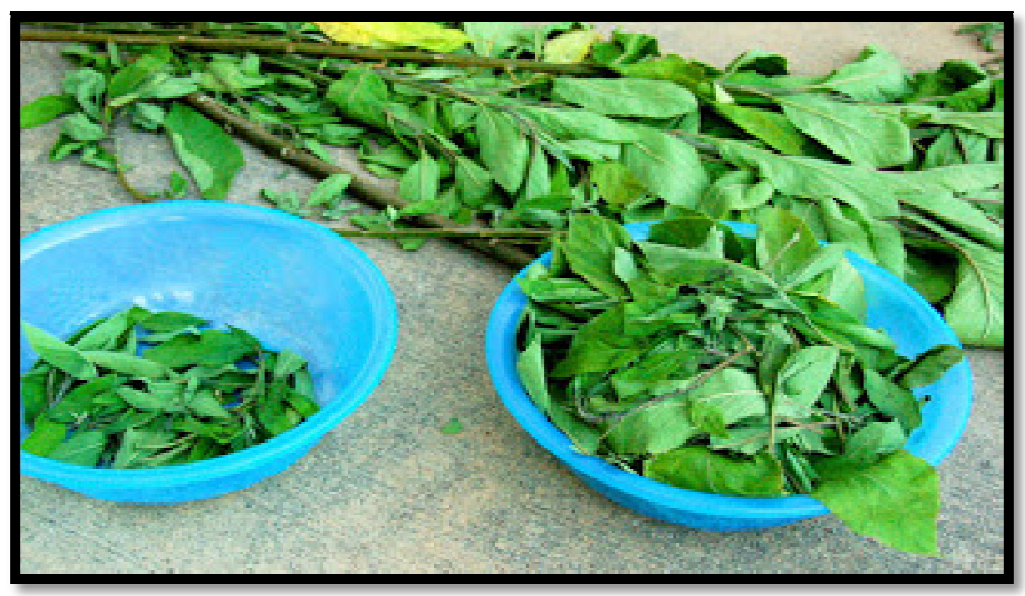

Figure 1: Leaves of Vernonia Amygdalina Used in the Study

\section{Preparation of Extract}

The leaves were sorted out to obtain only the fresh leaves and washed with distilled water without squeezing to remove debris and dust particles. They were shade dried for ten days and then, the dried leaves were pulverized with LG electric grinding machine. A portion, $(600 \mathrm{~g})$ of the powdered leaves were soaked in $2400 \mathrm{ml}$ of $70 \%$ ethanol for 72 hours with the solution thoroughly stirred twice daily. The extracts were then be filtered with WHATMAN no1 filter paper. The filtrate was air dried and then reconstituted with distill water later.

\subsection{Chemicals}

Alloxan monohydrate (Sigma, St Louis MO, USA) was used to induce diabetes in the rats, glimepiride with a brand name AMARYL (Sanofi-Aventis)

\subsection{Animals}

Adult albino rats of Wister strain weighing 200-250g of either sex were purchased from the disease-free stock of the animal house of the College of Health Sciences, Benue State University, Makurdi and used for the study. They were maintained in normal and standard laboratory conditions of temperature $28^{\circ} \mathrm{C}$ and relative humidity (with 12-hour light dark cycle) and adequate ventilation. The animals were fed with commercial diet (Vital Feed Nig.Ltd.) and water ad libitum. Food was withheld 8 hours before the experiments, but they had free access to water. Permission for the use of animals and animal protocols were obtained from the Animal Ethics Committee of Benue State University Makurdi, prior to the experimentation.

\subsection{Animal Categorization}

The animals were allowed 14-day acclimatization period, after which they were randomly allocated into five groups of 5 rats per group: $(n=5)$

\section{Induction of Diabetes}

Diabetes was induced on group 2, 3, 4 and 5 by intraperitoneal injection of alloxan monohydrate $(6.5 \mathrm{mg} / 100 \mathrm{~g})$ in normal saline $(0.9 \% \mathrm{NaCl})$, Osikwe et al.,2015, Onahinon et al.,2018. 50\% glucose solution was given to prevent initial 
hypoglycaemia caused by alloxan. Diabetes was confirmed three days later in alloxan- induced animals showing fasting blood sugar (FBS) level $\geq 126 \mathrm{mg} / \mathrm{dl}$ by using glucometer to monitor the blood sample from the tail vein.

\subsection{Animal Grouping and Experimental Design}

The animals will be randomly allocated into five (5) groups of 5 animals per group $(n=5)$

Group1: non diabetic control given normal saline

Alloxan induced.

Group 2: diabetic control given normal saline

Group 3: given 100mg/ kg of VA

Group 4: given 2mg/ kg glimepirideg

Group 5: given $2 \mathrm{mg} / \mathrm{kg}$ glimepiride and $100 \mathrm{mg} / \mathrm{kg}$

\begin{tabular}{|c|l|l|l|l|}
\hline Group & $\begin{array}{l}\text { Before Alloxan } \\
\text { Fbs } \pm \text { Sem } \\
\text { (Mg/ Dl) }\end{array}$ & $\begin{array}{l}\text { After Alloxan } \\
\text { Fbs } \pm \text { Sem } \\
\text { (Mg/ Dl) }\end{array}$ & $\begin{array}{l}\text { After N.Saline/ Va/ } \\
\text { Glim/ Va+Glim } \\
\text { Fbs } \pm \text { Sem (Mg/ Dl) }\end{array}$ & $\begin{array}{l}\text { \% Change } \\
\text { Fbs }\end{array}$ \\
\hline 1 & $81 \pm 2.8$ & - & - & - \\
\hline 2 & $81 \pm 2.1$ & $283 \pm 8.3$ & $340 \pm 20.3$ & $20.1 \%$ \\
\hline 3 & $84 \pm 2.4$ & $304 \pm 3.8$ & $198 \pm 3.3$ & $-34.9 \%$ \\
\hline 4 & $84 \pm 3.1$ & $308 \pm 3.3$ & $216 \pm 1.5$ & $-29.9 \%$ \\
\hline 5 & $86 \pm 1.4$ & $333 \pm 8.9$ & $151 \pm 5.1$ & $-54.7 \%$ \\
\hline
\end{tabular}

Table1. Fasting Blood Glucose of Wister Albino Rats Before and After Induction of

Diabetes with Alloxan and After Treatment with Vernonia Amygdalina,

Glimepiride and Combination of Both Agents

$\mathrm{MEAN} \pm \mathrm{SEM} n=5$

Table1 shows the fasting blood glucose of Wister albino rats before induction of diabetes with alloxan. It can be seen that the fasting blood glucose of the rats were within the physiologic range and there was no significant difference between the groups are shown in table 2 (Levene test of homogeneity). $\mathrm{p}>0.05$

\begin{tabular}{|c|c|c|c|c|}
\hline \multicolumn{5}{|c|}{ Test of Homogeneity of Variances } \\
\hline & $\begin{array}{c}\text { Levene } \\
\text { Statistic }\end{array}$ & Df1 & Df2 & Sig. \\
\hline Fbs After Alloxan & 1.854 & 3 & 15 & .181 \\
\hline Fbs Before Alloxan In & .215 & 3 & 15 & .885 \\
\hline
\end{tabular}

Table 2

Table 2 shows the Levene Homogeneity test of Variance. It shows that there was no significant difference between groups before inducing diabetes with alloxan and also, there was no significant difference between groups after the animals became diabetic by the administration of alloxan $(p>0.05)$

\begin{tabular}{|c|c|c|c|c|c|}
\hline \multicolumn{6}{|c|}{ ANOVA } \\
\hline & $\begin{array}{c}\text { Sum Of } \\
\text { Squares }\end{array}$ & Df & Mean Square & F & Sig. \\
\hline Between Groups & 159920.183 & 4 & 39980.046 & 129.074 & .000 \\
\hline Within Groups & 5885.150 & 19 & 309.745 & & \\
\hline Total & 165805.333 & 23 & & & \\
\hline
\end{tabular}

Table 3: Analysis of Variance after Treatment of Alloxan Induced Diabetic Rats With Vernonia Amygdalina/ Glimepiride/ Va +Glimepiride

Table 3 showed the Analysis of Variance (ANOVA) after treatment of diabetic rats in group 2, 3, 4 and 5 with normal saline, $100 \mathrm{mg} / \mathrm{kg}$ VA, $2 \mathrm{mg} / \mathrm{kg}$ glimepiride and $2 \mathrm{mg} / \mathrm{kg}$ glimepiride $+100 \mathrm{mg} / \mathrm{kg}$ V.amygdalina. The result shows that there was a significant difference between diabetic control group and the group treated with either VA or glimepiride alone and as well as when combine $(\mathrm{P}<0.01)$. 
Turkey's post Hoc analysis was used to determine where the significant difference was. From Turkey's post Hoc analysis, there was no significant difference between $100 \mathrm{mg} / \mathrm{kg}$ of VA and $2 \mathrm{mg} / \mathrm{kg}$ of glimepiride $(\mathrm{P}>0.05)$. There was a significant difference between the group treated with $100 \mathrm{mg} / \mathrm{kg}$ of VA $+2 \mathrm{mg} / \mathrm{kg}$ glimepiride and the group treated with monotherapy of either VA or glimepiride $(\mathrm{p}<0.01)$

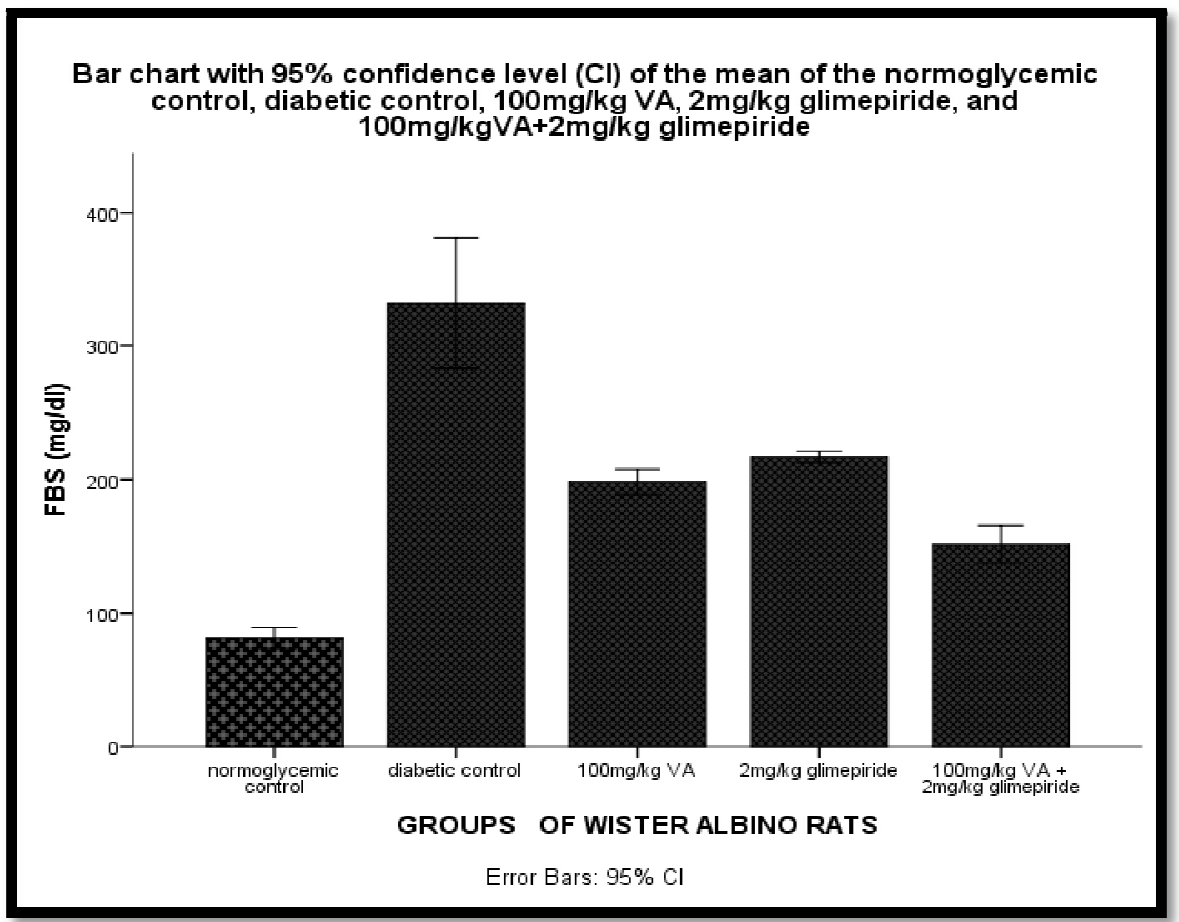

Figure 2

From fig 2, There was significant difference between the normoglycemic control group and diabetic control group $(p>0.05)$ which shows that alloxan significantly increase fasting blood glucose. There was a significant difference between Diabetic control group and group given $100 \mathrm{mg} / \mathrm{kg} \mathrm{VA}, 2 \mathrm{mg} / \mathrm{kg}$ glimepiride and the group with VA+glimepiride $(\mathrm{p}<0.01)$.

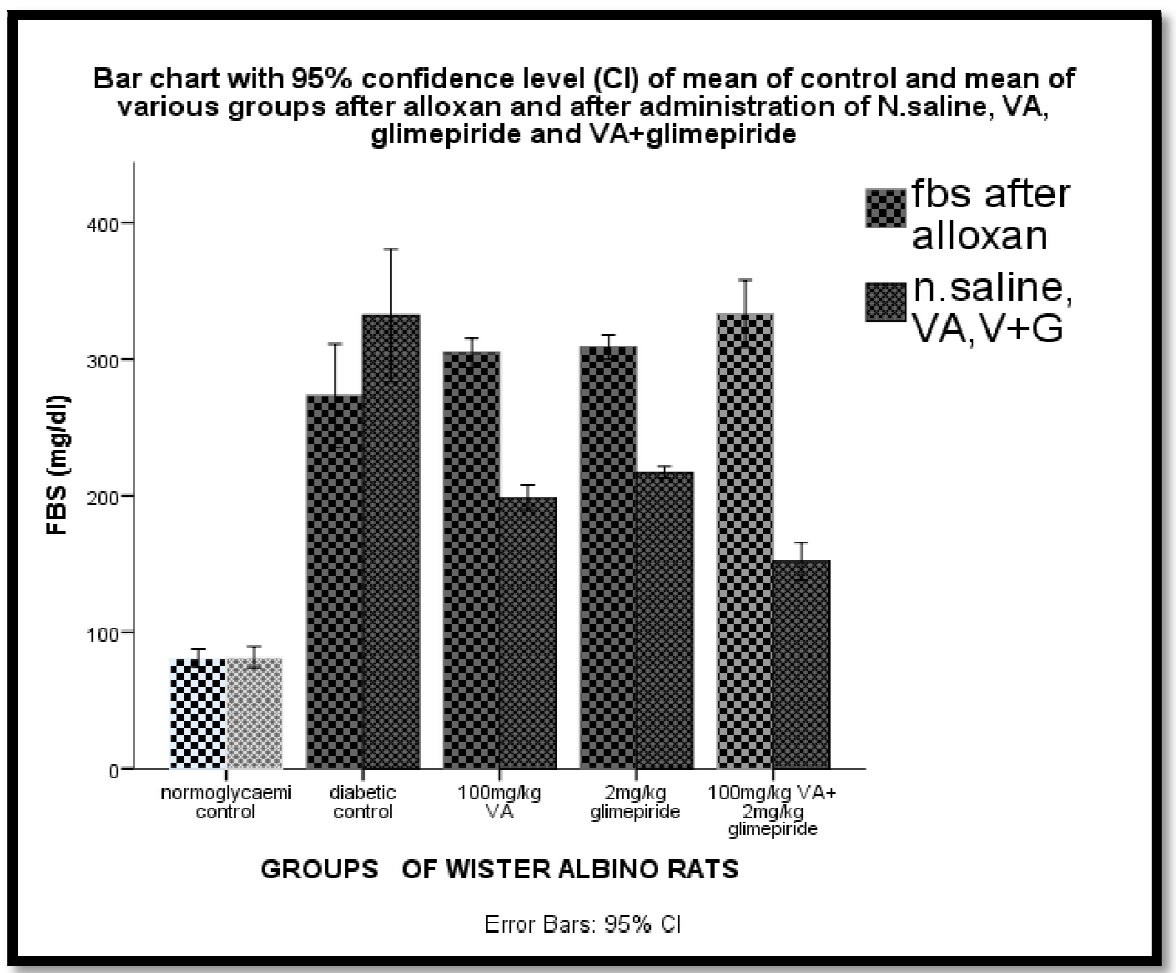

Figure 3 
Figure 3 shows the change in the mean of fasting blood glucose after administration of alloxan monohydrate and after administration of normal saline, $100 \mathrm{mg} / \mathrm{kg}$ VA, $2 \mathrm{mg} / \mathrm{kg}$ glimepiride, and $100 \mathrm{mg} / \mathrm{kg}$ VA+2mg/ kg glimepiride. There was an increase in fasting blood glucose of the diabetic control given normal saline as diabetes worsen if appropriate hypoglycaemic agent is not used. There was a significant difference between fasting blood glucose after alloxan administration and after treating the various groups with $100 \mathrm{mg} / \mathrm{kg} \mathrm{VA,} 2 \mathrm{mg} / \mathrm{kg}$ glimepiride and $100 \mathrm{mg} / \mathrm{kg}$ VA+2mg/ kg glimepiride $(\mathrm{p}<0.01)$.

\section{Discussion}

One of the hallmark of type 2 diabetes is the progressive decline in beta-cell function (ADA, 2009). B-cell function continues to deteriorate in association with progressively increasing hyperglycemia despite treatment (ADA, 2009). As betacell function continue to decline, monotherapy failure (define as FPG $>180 \mathrm{mg} / \mathrm{dl}$ ) is almost inevitable (Kahn et al.,2006). Monotherapy of sulfonylurea was showed to have the highest secondary failure rate overtime (Kahn et at., 2006), this may be due to increase in the production of Reactive Oxygen Species as explained by Kesavulu et al., 2000. There is an increasing evidence that oxidative stress caused by free radicals contribute to the development of diabetes mellitus (Mahdi et al., 2003)

Alloxan induced diabetic animal model is a valuable model of study that exhibit diabetic complication mediated through oxidative stress (Jorns et al., 1997). Glimepiride is a sulfonylurea whose mechanism of action is to stimulate insulin release from the B-cell of the pancreas. Thus, damage of beta-cell by oxidative stress affects the efficacy of glimepiride.

The result from this study shows that there was a significant reversal of alloxan induced hyperglycemia by Vernonia amygdalina $(p<0.01)$. This study agrees with the study of Owolabi et al., 2011 which stated that Vernonia amygdalina attenuates oxidative damage on pancreatic $b$ cell in alloxan induced diabetes. The reduction of fasting blood glucose by VA in alloxan induced diabetes is as a result of several active constituents that have been reported to be present in VA extract (Mukwaya et al.,2016). These phytochemicals include Saponins, Phenols, Tannins, Flavonoids, Terpenes and Glycosides (Mukwaya et al.,2016). It has been shown that flavonoids possess remarkable hypoglycaemic effect (Cazarolli et al., 2008). This effect has been linked to its ability to impair glucose absorption and improve glucose tolerance (Cazarolli et al., 2008). Flavonoid have also been shown to be potent antioxidant agent that impair the generation of free radicals (El-Abhar, and Schaalan, 2014).

The result from this study showed that co administration of Vernonia amygdalina with glimepiride offered a reduction in fasting blood glucose that was significantly different from either VA or glimepiride alone $(p<0.01)$. This suggest that VA attenuates beta cell pancreatic damage caused by alloxan and thus allow glimepiride to have a better effect on the beta cell to secrete insulin. Thus, VA and glimepiride exhibit synergism.

Vernonia amydalina may prolong the secondary failure of sulfonylurea when co administered.

\section{Recommendation}

Public Health Education is advocated from the results of this study.Diabetic patients who are experiencing problem with monotherapy with glimepiride should be given health advice to combine their treatment with use of Vernonia amgydalina o enhance efficacy of the therapy due to the synergistic effect of the two agents.

\section{References}

i. Akah, P.A., Okoli, C.O. and Nwafor, S.V. (2002) Phytotherapy in the Management of Diabetes Mellitus. Journal of Natural Remedies, 2, 1-10

ii. American Diabetes Association (2009) Clinical practice recommendations. Diabetes Care 21:s1 - s70

iii. Cazarolli, L.H., Zanatta, L., Alberton, E.H., Figueiredo, M.S., Folador, P., Damazio, R.G., Pizzolati, M.G. and Silva, F.R. (2008) Flavonoids: Cellular and Molecular Mechanism of Action in Glucose Homeostasis. Mini-Reviews in Medicinal Chemistry, 8, 1032-1038.

iv. El-Abhar, H.S. and Schaalan, M. (2014) Phytotherapy in Diabetes: Review on Potential Mechanistic Perspectives. World Journal of Diabetes, 5, 176-197 Kesavulu, M. M., Giri, R., Kameswara, R. B., Apparao, C. (2000). Lipid peroxidation and antioxidantenzyme levels in type 2 diabetics with microvascular complications. Diabetes metabolism, 26(5), 387-92.

v. Kjems LL, Kirby BM, Welsh EM, Veldhuis JD, Straume M, McIntyre SS, Yang D, Lefebvre P, Butler PC. (2001) Decrease in beta-cell mass leads to impaired pulsatile insulin secretion, reduced postprandial hepatic insulin clearance, and relative hyperglucagonemia in the minipig. Diabetes. 50:12

vi. Jorns A, Munday R, Tiedge M, Lenzen S (1997). Comparative toxicity of alloxan, N-alkyl-alloxans and ninhydrin to isolated pancreaticislets in vitro. J. Endocrinol. 155:283-93

vii. Mahdi AA, Chandra A, Singh RK, Shukla S, Mishra LC, Ahmad S.Effect of herbal hypoglycemic agents on oxidative stress andantioxidant status in diabetic rats. Indian Journal of ClinicalBiochemistry 2003; 18(2):8-15

viii. Mukwaya Z, Engoru T, Kainza EJ, Inyani JK, Buligwanga S, Munanura EI, Kalidi R, Mugisha M, Adome , Anyama N, Kamba P, Kaggwa B (2016). Efficacy of A Syrup Formulated from Combined Extracts of Vernonia Amygdalina And Musa Paradisiaca For the Management of Type 2 Diabetes. African Journal of Pharmaceutical Research \& Development Vol. 8 No. 2; pp. 71-80 
ix. Onahinon C., Eru E., Ibu J (2018). Effect of Vernonia amygdalina Found in Alloxan Induced diabetes. International Journal of Research and Development: Vol 7, 154-159

x. Osigwe, C., Akah, P., Nworu, C., Okoye, T. and Tchimene, M. (2015) Antihyperglycemic Studies on the Leaf Extract and Active Fractions of Newbouldia laevis (Bignoniaceae). Pharmacology \& Pharmacy, 6, 518-532

xi. Sharma VK, Kumar S, Patel HJ, Hugar S (2010). Hypoglycemic activityof Ficus glomerata in alloxan induced diabetic rats. International Journal of Pharmaceutical Sciences Review and Research 1(2):18-22.

xii. Tanaka T, Tong HH, Xu Y, Ishimaru K, Nonaka G, Nishioka (1992). Tannins and related compounds: Isolation and characterization of three new ellagitannins, lagerstannins A, B and C, having a gluconic acid core, from Lagerstroemia speciosa (L.) Chem and Pharmaceu Bull Tokyo. 1992;40(11):2975-2980

xiii. Tiwari A K and Rao J M (2002) Diabetic mellitus and multiple therapeutic approaches of phytochemicals: Present status and future prospects. Curr. Sci. 83 30-37

xiv. Turner RC, Cull CA, Frighi V, Holman RR (2000) Glycemic control with diet, sulfonylurea, metformin, or insulin in patients with type 2 diabetes mellitus: progressive requirement for multiple therapies (UKPDS 49), UK Prospective Diabetes Study (UKPDS) group. JAMA 281: 2005-2012

xv. Verspohl, E.J. (2012) Novel Pharmacological Approaches to the Treatment of Type 2 Diabetes. Pharmacological Reviews, 64, 188-237 